\title{
Uncommon Disturbance of Root Development after Tooth Replantation. Five-Year Follow-up Period Case Report
}

\author{
Trastorno del Desarrollo Radicular Poco Frecuente Posterior a Reimplante Dentario. \\ Reporte de Caso con 5 Años de Seguimiento
}

Diaz J. A.; ; Nuñez J.* \& Camilla M.*

DIAZ, J. A.; NUÑEZ, J. \& CAMILLA, M. Uncommon disturbance of root development after tooth replantation. Five-year follow-up period case report. Int. J. Odontostomat., 10(3):491-498, 2016.

ABSTRACT: To present an uncommon disturbance of root development with ingrowth of bone and periodontal tissue into the pulp space in a delayed replanted immature permanent incisor at five years of follow-up. Severe arrest of root formation with uncommon healing of an immature permanent maxillary incisor after delayed replantation is reported. Continued development of a tooth root separate from the body of the tooth was not observed. A 6-year-old girl sustained an avulsion injury to her upper left central permanent incisor. The tooth was replanted and splinted 2 hours after the accident. Patient has been monitored clinically and with radiography for 5 years. The periodontal tissues presented good healing without replacement resorption. However, severe arrest of root formation with development of hard-like tissue and internal periodontal ligament inside the pulp canal have been observed. Despite being a delayed tooth replantation, the patient has been asymptomatic, and has maintained alveolar bone volume. Clinicians must be vigilant and monitor traumatized immature teeth closely.

KEY WORDS: tooth Replantation, root develoment, avulsion injury.

\section{INTRODUCTION}

Over the past 12 years, the literature has reported high prevalence of dental injuries, particularly in children between 7 and 12 years of age (Glendor, 2008). Usually, the most affected teeth are the upper maxillary central incisors, which are erupting and have a periodontal ligament (PDL) with minimal resistance to an extrusive force, and a thin buccal alveolar plate. It has been shown that approximately $35 \%$ of all avulsions occur before the age of 9 , i.e. usually before full incisor root development, where the effects of traumatic injury can be very destructive (Andreasen et al., 1995b; Andreasen et al., 1995c \& Andreasen et al., 1995d).

It is currently known that the healing process after traumatic dental injury is very complex, involving multiple and different types of cells (pulp, periodontal ligament, alveolar bone) with different healing potentials (Andreasen et al., 2013). Accordingly, there are two possible healing scenarios after dental trauma: tissue regeneration and tissue reparation. The former is a biological process where the new tissue restores structure and function, whereas the second involves the formation of a non-functional scar tissue (Bourne \& Wilson, 1964; Andreasen \& Bakland, 2012; Andreasen, 2012).

The great variability of cells that participate in post-trauma healing, i.e., after extrusive luxation and replantation of avulsed permanent teeth, may explain the different clinical and imaging results during monitoring and follow-up. Events related to PDL healing include: (I) repair-related root resorption, (II) infectionrelated root resorption, (III) cervical invasive root resorption, (IV) loss of marginal bone, and (V) ankylosis-related root resorption. Events related to pulp behavior include: (I) pulp canal obliteration (PCO), (II) root canal resorption (repair and infection-related), and (III) tissue metamorphosis, where PDL and cementum are found inside the pulp (Andreasen \& Bakland).

The prognosis of replanted permanent teeth depends on several factors, such as stage of root development at the time of injury, the moment of

"Pediatric dentistry Department, Faculty of Dentistry, Universidad de La Frontera, Temuco, Chile. 
replantation, storage medium and transport of the avulsed tooth prior to replantation (Andreasen et al. 1995b; Andreasen et al; 1995c; Andreasen et al. 1995d; Barrett \& Kenny, 1997). The literature has described the healing complications that affect the different tissues affected in replanted permanent incisors. The most common healing complications of avulsed permanent teeth are infection-related root resorption (inflammatory root resorption-IRR) and ankylosis-related root resorption (replacement resorption-RR), which are associated with pulp necrosis and extended damaged to the root surface and PDL, respectively.

There are three types of root growth, which can be classified radiographically according to the $\mathrm{x}$-ray imaging appearance: complete development, partial completion and total arrest. In immature permanent teeth, the Hertwig root sheath (HERS) is usually sensitive to trauma; however, in some circumstances it may resist damage from trauma and infection. Furthermore, there have been cases where some teeth healed with arrested root development with an ingrowth of bone and periodontal tissue into the pulp space. In other cases, full root length was achieved regardless of pulp status (normal or necrotic).

Although healing capacity after a dental trauma of immature permanent tooth roots has been shown in various case reports, there are few published clinical cases that have reported partial or total arrest of root development with internal periodontal ligament after permanent tooth replantation (Rule \& Winter, 1966; Gibson, 1969; Burley \& Reece, 1976; Welbury \& Walton, 1999). Usually, this phenomenon occurs after lateral luxation, intrusive luxation or replantation of teeth with immature root formation (Andreasen, et al. 2013).

The aim of this report is to show the disturbances of root development and ingrowth of internal bone and periodontal tissue into the pulp space in a delayed replanted immature permanent incisor during five years of follow-up.

\section{CASE REPORT}

In January 2010, a healthy six-year-old girl sought emergency attention due to bicycle accident with traumatic avulsion of the upper left maxillary central incisor. Initial emergency treatment resulting in replantation of affected tooth 2 hours post-trauma. The avulsed incisor was transported and stored in a non- recommended medium (glass with tap water). The tooth was replanted and stabilized with a wire composite splint in the local emergency room.

The patient was referred to a specialist clinic, presenting with a 2-3 mm extruded position of the affected tooth and rigid wire-composite splint in a nonphysiological gingival location. The splint was removed and the affected tooth repositioned with gentle and soft digital pressure re-stabilizing. This was achieved with a splint in a physiologically correct position. The patient received oral antibiotic therapy for 10 days. Radiograph revealed that tooth 21 had an immature root formation (Stage 3 modified according to Moorrees), open apex, and incomplete replantation or partial displacement from the alveolar socket. There were no apparent signs of a root fracture or damage to adjacent teeth and bone structures (Fig.1). The patient and her parents were informed about maintaining good oral hygiene, brushing twice a day, soft diet and mouth rinses with chlorhexidine for 2 weeks. The patient was not required to be immunized against tetanus, since all children in Chile are immunized and protected until the age of 15 . The patient and her parents were informed and signed informed consent for publication.

According to IADT guidelines, the splint was removed 4 weeks post-trauma. The first goal of this treatment was to wait for revascularization and observe continuing root development. The patient was referred for clinical and radiographic assessment of the replanted tooth for prompt diagnosis of pulp and/or PDL potential healing complications. During the clinical and radiographic monitoring, the pulp and the periodontal ligament diagnosis, and the state of root development of the compromised tooth was performed according the parameters that appear in Table I. (Andreasen et al., 1995a; Andreasen et al., 1995b; Andreasen et al. 1995c; Andreasen et al., 1995d). According to final clinical and radiographic findings, the outcome of the replanted tooth may be classified either as complete success, acceptable success, or failure. (Table II).

Two months later, clinical assessment of the replanted tooth revealed a slight metallic sound to percussion test, no mobility, no infraposition, no abnormal crown discoloration. Nevertheless, it presented slight pain at palpation of the vestibule. In light of this clinical scenario, tooth ankylosis and pulpal pathosis were suspected. In order to define and/or confirm the pulp status diagnosis, a cavity test was performed with high velocity rotatory instruments. During the clinical procedure, the patient presented 
Table I. Parameters to definition healing, pulp periodontal complications in replanted tooth

\begin{tabular}{|c|c|c|}
\hline & Clinical Examination & Radiological Examination \\
\hline Healing; pulp survival and functional $P$ & $\begin{array}{l}\text { Normal Mobility } \\
\text { Normal sound and percussion test } \\
\text { Normal eruption } \\
\text { Recovered prop rioceptive function }\end{array}$ & $\begin{array}{l}\text { Surrounding tissue of the root presented a newly } \\
\text { formed periodontal space and complete lamina dura. } \\
\text { No Periapical or periradicular radiolucences } \\
\text { Little resorptions not related to infection or } \\
\text { ankylosis (surface resorption) }\end{array}$ \\
\hline $\begin{array}{l}\text { Replacement resorption /ankylosis R.F } \\
\text { Infection related pulp necrosis of pulp }\end{array}$ & $\begin{array}{l}\text { Percussion test: high metallic sound } \\
\text { No mobility } \\
\text { Progress Infraoclussion } \\
\text { Spontaneous pain }\end{array}$ & $\begin{array}{l}\text { Partial or complete loss of period ontal space } \\
\text { Absent of lamina dura } \\
\text { Replacement of root tissue by bone } \\
\text { Periapical or periradicular radiolucences }\end{array}$ \\
\hline & $\begin{array}{l}\text { Pain to percussion test and/or to palpation of } \mathrm{v} \\
\text { Swelling } \\
\text { Pathological Mobility } \\
\text { Abscesses and or fistulae }\end{array}$ & $\begin{array}{l}\text { Bowl-shaped resorption along the root surface } \\
\text { Absent of lamina dura. }\end{array}$ \\
\hline Root development & & $\begin{array}{l}\text { No arrest: replanted teeth reached approximately the } \\
\text { Same length }( \pm 1 \mathrm{~mm}) \text { of non replanted counterpart tooth. } \\
\text { Total arrest: replanted teeth show no further root } \\
\text { Formation Partial arrest: root formation cannot be } \\
\text { classified as no arres or arrested. }\end{array}$ \\
\hline
\end{tabular}

Table II Evaluation criteria of the results related to replantation procedure in immature permanent teeth

\begin{tabular}{|c|c|c|}
\hline Complete Success & Acceptable successful & Failure \\
\hline $\begin{array}{l}\text { Healing; pulp survival and functional PDL } \\
\text { Abscense of pathological clinical and } \\
\text { radiographic signs. } \\
\text { Normal Mobility } \\
\text { Normal sound and percussion test } \\
\text { Normal eruption } \\
\text { Complete root development } \\
\text { Pulp canal obliteration } \\
\text { Recovered proprioceptive function }\end{array}$ & $\begin{array}{l}\text { Abscense of pathological clinical and } \\
\text { radiographic signs. } \\
\text { Tooth with endodontic treatment } \\
\text { Normal Mobility } \\
\text { Normal sound and percussion test } \\
\text { Normal eruption } \\
\text { Partial root development } \\
\text { Recovered prop rioceptive function }\end{array}$ & $\begin{array}{l}\text { Complete loss of periodontal space } \\
\text { Absent of lamina dura } \\
\text { Replacement of root tissue by bone } \\
\text { Periapical or periradicular radiolucences } \\
\text { Bowl-shaped resorption along the root } \\
\text { Surface Percussion test: high metallic } \\
\text { Sound No mobility } \\
\text { Progress Infraoclussion }\end{array}$ \\
\hline
\end{tabular}

Source: Modified from Soares A de J et al., ( Dent Traumatol, 2008).

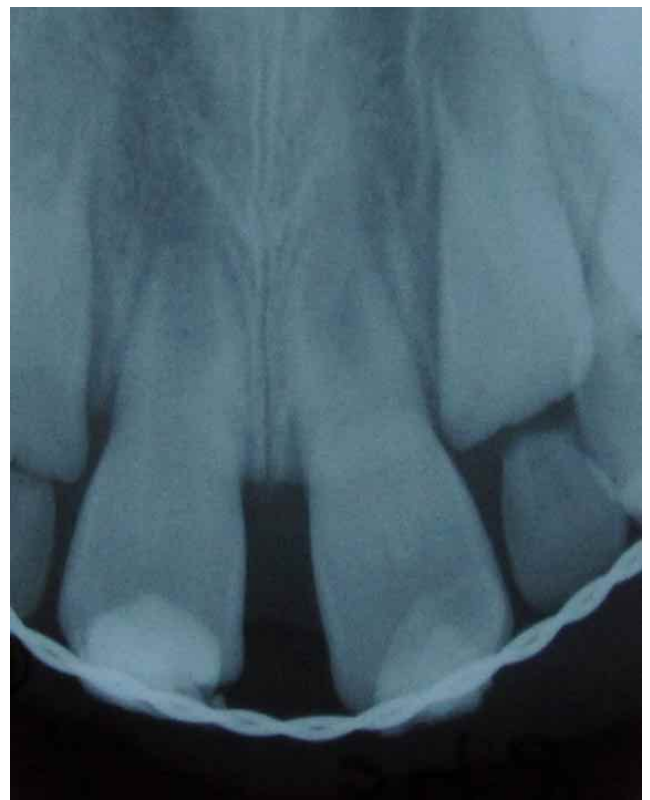

Fig.1. Immediate radiographic control of replanted upper left maxillary central incisor at initial presentation. Observe incomplete replantation and immature root formation of both central incisors. acute pain and sensibility; the procedure was halted, and immediate restoration with glass ionomer cement was performed (Ketac Molar 3M ESPE®). To confirm the healing status of hard periodontal tissues, the patient was evaluated with radiographic examination, which showed normal periodontal structures, preserved lamina dura, immature root formation, no image of apical osteitis, and no replacement resorption of the root (Fig. 2). During this control, the pulp and periodontal diagnosis corresponded to: pulp survival and functional PDL. There may be the presence of transient ankyloses.

Eighteen months after the replantation (July, 2011), the affected tooth presented normal sound in the percussion test, mobility and slight infraposition, perhaps associated with tongue dysfunction. Radiograph showed clear signs of severe arrest of root development, normal lamina dura and periodontal space, and no evidence of root resorption. A radiopaque structure with internal bone formation and periodontal ligament inside the root canal was noteworthy (Fig. 3). The pulp and PDL status in this control corresponded to pulp survival and functional supporting tissues. 


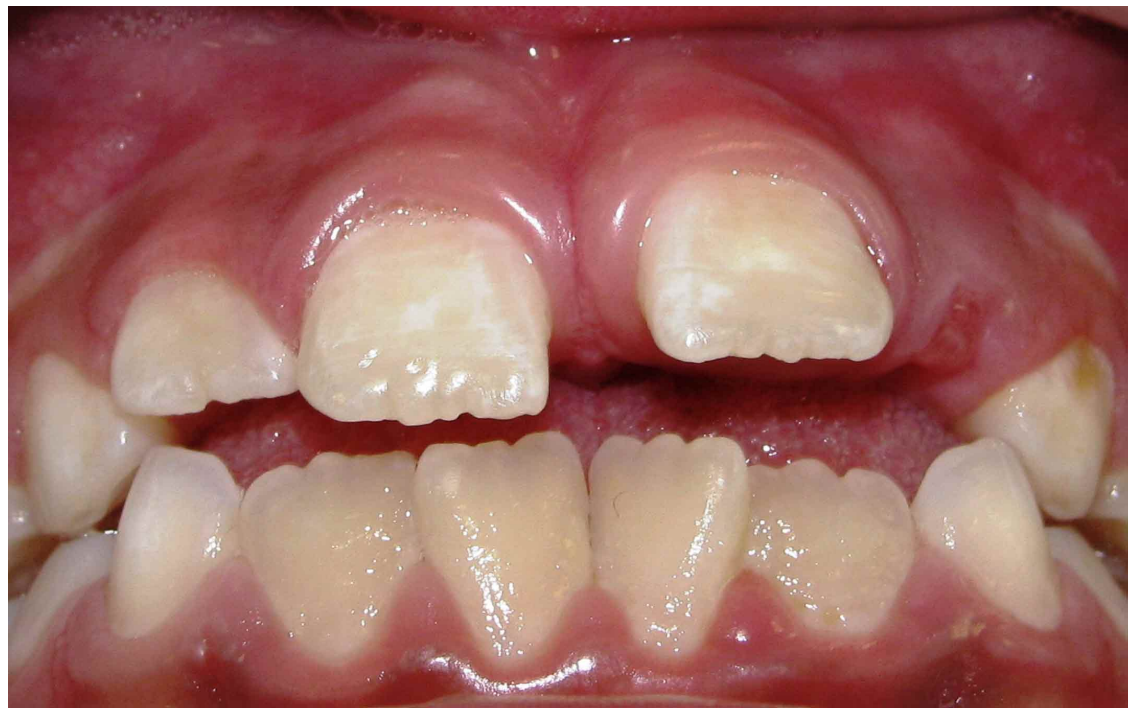

Fig. 2a. Frontal view after 2 months showing an open bite and tooth 21 with vestibular displacement

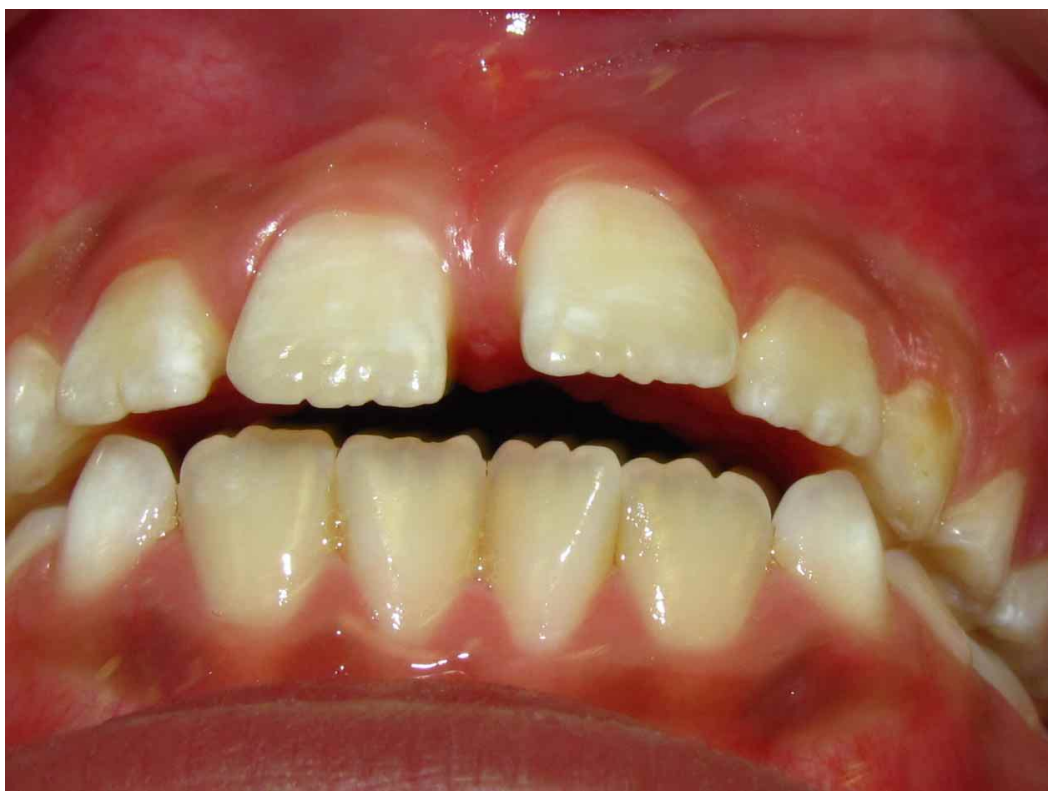

Fig. 3a Clinical frontal view after 18 months. Observed slight protrusion of tooth 21 , maybe associated to tongue and perioral muscle dysfunction.

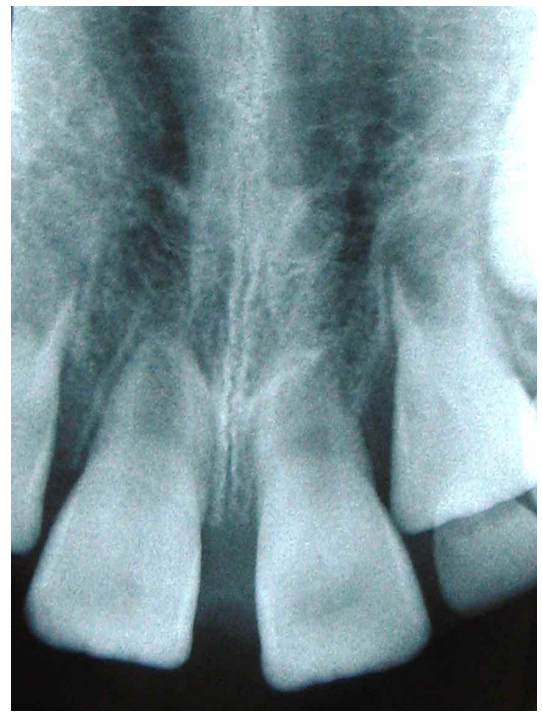

Fig. 2b. Periapical radiograph 2 months after trauma shows normal periodontal structures in tooth 21.

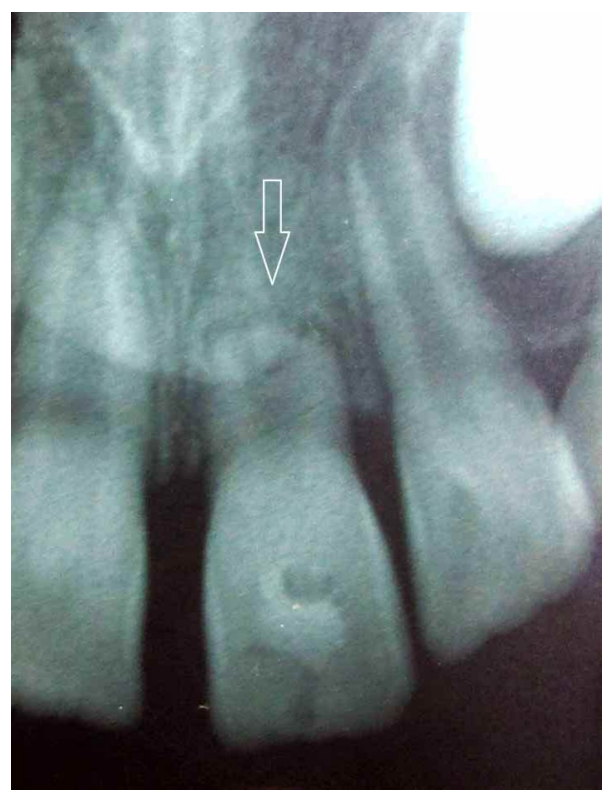

Fig. 3b. Radiographic control shows severe arrest of root development and no evidence of replacement root resorption. Compatible image with early calcific changes within the pulp canal.
In August 2013, the patient presented a new traumatic injury: An extrusive luxation with 1-2 mm axial displacement of the same permanent incisor. The tooth was repositioned and splinted for 2 weeks. Following this traumatic injury, the affected upper central incisor had shown no complications in supporting tissues. In December 2014, the clinical examination was noncontributory in terms of new negative healing events; the tooth presented functional location in the arch, asymptomatic, without crown discoloration, normal percussion test and with severe arrest of root development, with ingrowth of bone tissue and PDL into the pulp canal. The radiopaque bone tissue in the pulp canal appeared to be surrounded by a radiolucent space similar to the periodontal membrane (Fig. 4). After 5 years, the option of root canal therapy was not 
considered due to the continued normal functioning of the tooth and the absence of other clinical signs and symptoms suggestive of pathological changes.

In the absence of any untoward pathosis and reporting by the child and parents of continued normal functioning of the tooth, the situation will continue to be monitored clinically and radiographically. Throughout the observation period, the child's parents were fully informed of the status of the tooth and the changes observed.
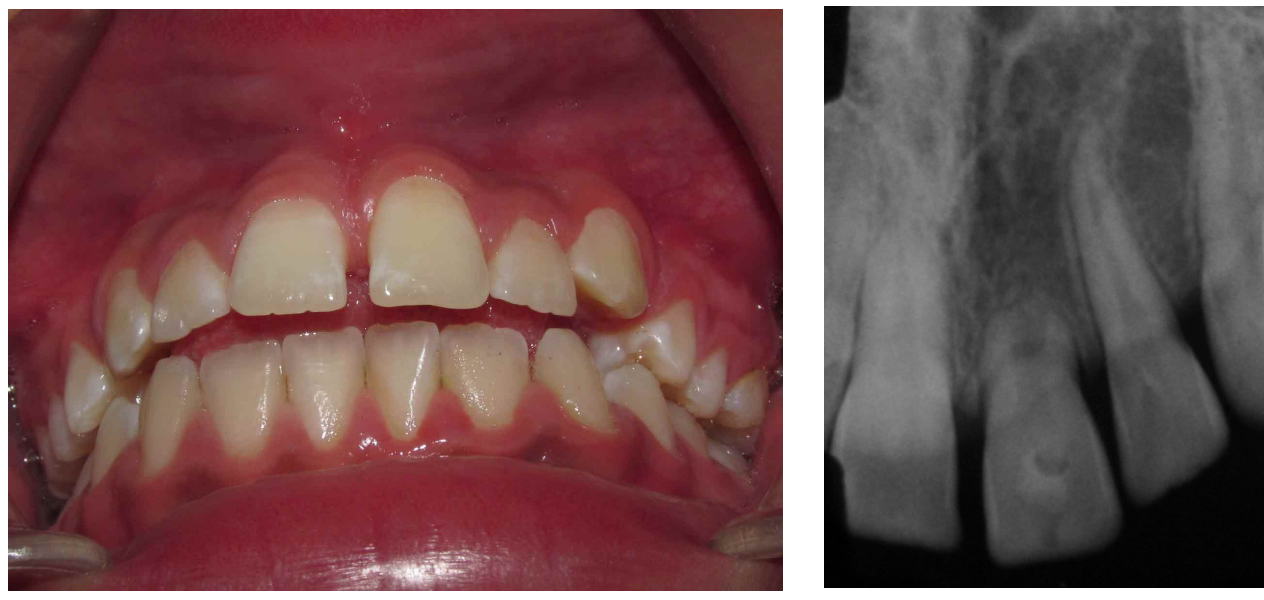

Fig. 4b. Radiographic control of affected incisor 60 months after trauma showing severe arrest of root development. Root canal is filled with radioopaque mass compatible with ingrowth of bone like tissue into the pulp canal.

Fig. 4a. Clinical view 5 years after replantation.

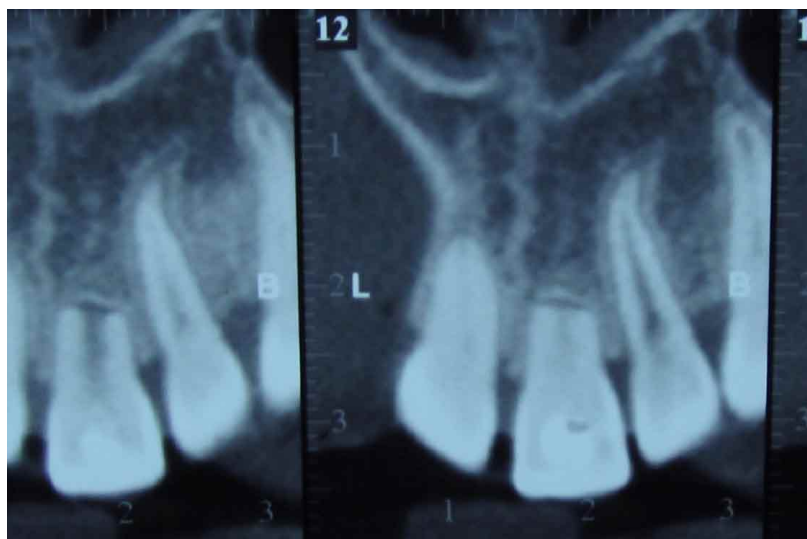

Fig. 4c.CBCT frontal view of tooth 21.

\section{3}
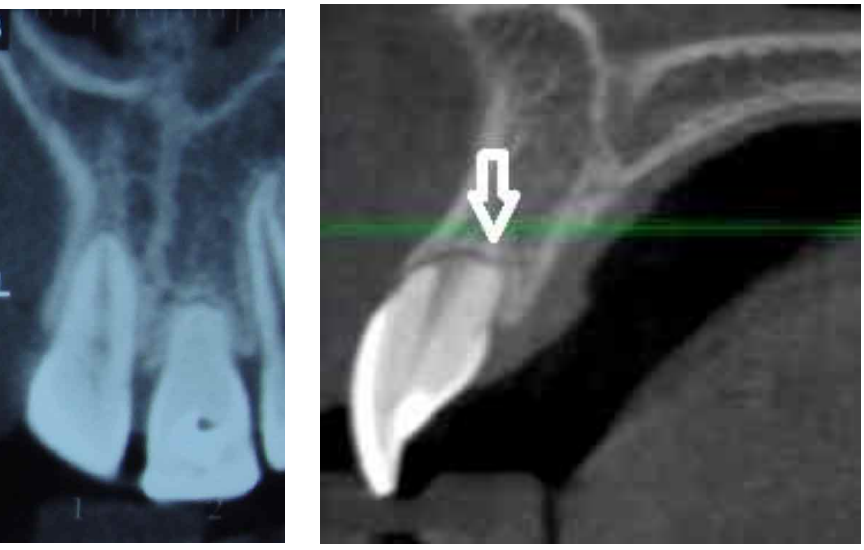

Fig. 4d. CBCT lateral view of tooth 21

\section{DISCUSSION}

The healing capacity of periapical tissues in immature and mature permanent teeth after dental trauma has been widely reported in the literature. Generally, in immature root formation, there are four different cell populations that may respond to the injury; (i) cells of the pulp and apical zone, (ii) cells of periodontal ligament, (iii) cells of alveolar bone and periosteal membrane, and, (iv) cells of the Hertwig root sheath (Andreasen).
In cases of permanent teeth with immature root formation, the traumatic injuries that can affect root development are avulsion, extrusive luxation and intrusive luxation. However, root development of permanent incisors may also be affected by the procedure of re-implantation and / or tooth reposition, and also by inadequate splinting and severe dentoalveolar injury in primary incisors in children under five years old. In young permanent teeth after an 
intrusive injury, the HERS is usually contused. (Andreasen; Andreasen \& Backland).

Although some published articles have described the changes and variations in root formation after tooth replantation, little is known of the different factors related to root growth subsequent to dental trauma and replantation (Andreasen \& Horting-Hansen, 1966; Kling et al., 1986). Many studies have looked at root growth subsequent to trauma and have highlighted the importance of the HERS in continued root formation. This damage can be reversible such that normal root growth resumes and apical closure follows. In other clinical situations a separation or cut of the HERS may occur at level of the pulpal papilla. After an avulsion injury to an immature tooth, the HERS can be detached from the coronal part, thereby creating a separated root tip. Then, in cases of avulsion of immature permanent teeth clinicians should be aware of the possibility that a new root tip can develop, and have continuous follow-ups of traumatized immature teeth to make an accurate diagnosis.

Rule \& Winter stated that root growth is only possible where the HERS has retained its specialized function (Andreasen \& Harting-Hansen). It is thought the HERS provides a source of undifferentiated cells that could give rise to further hard tissue formation. In addition, it may protect against the ingrowth of periodontal ligament cells into the root canal, which would result in intracanal bone formation and arrest of root development (Andreasen et al., 1995b; Andreasen et al., 1995c; Andreasen et al., 1995d). It should be noted that this type of healing should occur under noninfected pulp necrosis conditions (Andreasen et al., 1995a). Other authors have pointed out the powers of recovery of the dental papilla, probably due to its large number of undifferentiated mesenchymal cells.

The response capacity of HERS cells should be consistent with the magnitude of damage and the characteristics of the injury. In this case report, the affected tooth presented considerable cell damage to the HERS since there was an avulsion and delayed incomplete replantation of an immature central incisor with inadequate transport and storage medium and excessive extra-oral time. Another important factor to consider is the second traumatic event suffered by the same tooth 42 months from the first injury.

Experiments on monkeys have shown that the extent of damage to the HERS occurs during the initial trauma or during a prolonged or delayed and inadequate revascularization period in cases of incomplete replantation or inaccurate reposition after a luxation injury (Andreasen et al., 1988). This situation leads to bone invasion, PDL and cementum in the pulp canal, and detention of root development (Andreasen et al., 1995a; Andreasen et al., 1995b; Andreasen et al., 1995c; Andreasen et al., 1995d; Andreasen et al., 1988; Kristerson \& Andreasen, 1984). According to Andreasen et al. (1988; 1995a), ingrowth of bone and formation of internal periodontal ligament is related to arrested root formation in cases with pulpal healing. The explanatory factor for these findings appears to be damage to the HERS (Andreasen et al., 1995a; Andreasen et al., 1988). The explanation for events that occur over time when the cement surface, PDL and bone are present in the root canal come from a series of dental trauma clinical case reports and follow-up of immature teeth transplantation. This outcome indicates that the HERS has deteriorated severely, resulting in bone, cementum and PDL-derived cells entering the pulp cavity (Andreasen et al., 1988).

In this case, in spite of the replanted tooth responding to a percussion test with pain, the option of root canal therapy was not considered due to high dentinal sensibility and the absence of other clinical signs and symptoms suggestive of pathological changes. The periapical x-rays also showed root and periapical structures surrounded by normal periodontal tissues and bone. We must assess critically whether the vestibular displacement of tooth 21 after 2 months was due to: (i) ankylosis development given the characteristics of the re-implantation, or (ii) tongue and perioral muscle dysfunction.

Because it was a delayed replantation with extended non-physiological storage of the affected tooth, there was very low likelihood of cells of the periodontal ligament being viable; thus taking early development of ankyloses with replacement resorption into consideration is entirely feasible. Nevertheless, due to severe arrest of root development, the affected tooth presented a very small root area, which made displacement by muscle forces possible. In December 2014 the patient was evaluated by an orthodontist for Type II malocclusion, open bite and perioral muscle dysfunction.

Clinically, regular and systematic clinical and imaging follow-up is advisable in all trauma cases involving immature permanent teeth, which may result in disruption of the HERS. The check-up should include an adequate $x$-ray assessment, cone-beam computed tomography (CBCT), a complete clinical observation of the tooth, the 
presence or absence of sinus formation, outcome of sensitivity testing, mobility and percussion test.

It is necessary to know if this type of healing with ingrowth of cementum, PDL and bone formation in the pulp canal space will provide stability for the affected tooth and the patient. Is the development of internal ankylosis-related resorption with infraoclusion possible in the future? Is it feasible to subject this tooth to orthodontic treatment in the future?

If the final clinical outcome of this tooth is not favorable before the end of the patient's facial growth, we believe it has fulfilled an important principle to respect the patient's rights in terms of self-esteem, esthetics and maintenance of alveolar bone volume for future implant rehabilitation. Currently, in light of existing knowledge, and as long as the affected tooth presents no further complications, we are committed to maintaining regular long-term radiographic and clinical follow-up. This case further illustrates the capacity of the immature tooth structures to withstand considerable trauma and apparently retain their functionality.

\section{CONCLUSION}

This case report illustrates the clinical and radiographic outcome of delayed replantation of an immature permanent upper maxillary incisor. According to the patient outcome, it is possible to conclude that:

- Hertwig's epithelial root sheath is necessary for root growth.

- In severe dental trauma of immature permanent teeth (avulsion), the HERS may receive extended damage with the involvement root formation arrest.

- A long-term observation period strategy is needed to observe uncommon healing, such as internal bone formation with periodontal ligament.

- $\quad$ Regular long-term clinical and imaging follow-up and continuous monitoring of immature permanent teeth with history of severe trauma (avulsion, intrusion, lateral and extrusive luxation) is required.

DIAZ, J. A.; NUÑEZ, J. \& CAMILLA, M. Trastorno del desarrollo radicular poco frecuente posterior a reimplante dentario. Reporte de caso con 5 años de seguimiento. Int. J. Odontostomat., 10(3):491-498, 2016.

RESUMEN: El objetivo de este trabajo fue presentar una alteración poco frecuente del desarrollo de la raíz con el crecimiento del tejido óseo y periodontal en el espacio pulpar en un incisivo permanente inmaduro reimplantado de manera tardía, a los cinco años de seguimiento. Se observó una suspensión severa de la formación de raíces con cicatrización poco común, de un incisivo maxilar permanente inmaduro después de una reimplantación tardía. No se observó el desarrollo continuo de la raíz dentaria separada del diente. Una niña de 6 años de edad sufrió una lesión por avulsión en su incisivo central superior izquierdo. El diente fue replantado dos horas después del accidente. La paciente ha sido monitoreada clínicamente y con exámenes radiológicos durante 5 años. Los tejidos periodontales presentaron buena cicatrización sin reabsorción de reemplazo. Sin embargo, se ha observado una detención severa de la formación de las raíces, con desarrollo de tejido duro y ligamento periodontal interno dentro del canal pulpar. A pesar de ser una reimplantación tardía del diente, la paciente presenta asintomática, y ha mantenido el volumen del hueso alveolar. Los médicos deben estar atentos y mantener en observación los dientes inmaduros traumatizados.

PALABRAS CLAVE: reimplante dentario, desarrollo radicular, lesión por avulsión.

\section{REFERENCES}

Andreasen, J. O.; Borum, M. K. \& Andreasen, F. M. Replantation of 400 avulsed permanent incisors. 3. Factors related to root growth. Endod. Dent. Traumatol., 11(2):69-75, 1995a.

Andreasen, J. O.; Borum, M. K.; Jacobsen, H. L. \& Andreasen, F. M. Replantation of 400 avulsed permanent incisors. 1. Diagnosis of healing complications. Endod. Dent. Traumatol., 11(2):51-8, $1995 \mathrm{~b}$.
Andreasen, J. O.; Borum, M. K.; Jacobsen, H. L. \& Andreasen, F. M. Replantation of 400 avulsed permanent incisors. 4. Factors related to periodontal ligament healing. Endod. Dent. Traumatol., 11(2):76-89, 1995c.

Andreasen, J. O.; Borum, M. K.; Jacobsen, H. L. \& Andreasen, F. M. Replantation of 400 avulsed permanent incisors. 2. Factors related to pulpal healing. Endod. Dent.Traumatol., 11(2):59-68, 1995d. 
Andreasen, J. O. \& Horting-Hansen, E. Replantation of teeth. I. Radiographic and clinical study of 110 human teeth replanted after accidental loss. Acta Odontol. Scand., 24(3):263-86, 1996.

Andreasen, J. O.; Kristerson, L. \& Andreasen, F. M. Damage of the Hertwig's epithelial root sheath: effect upon root growth after autotransplantation of teeth in monkeys. Dent. Traumatol., 4(4):145-51, 1998.

Andreasen, J. O. Pulp and periodontal tissue repair regeneration or tissue metaplasia after dental trauma. A review. Dent. Traumatol., 28(1):19-24, 2012.

Andreasen, J. O. \& Bakland, L. K. Pulp regeneration after non-infected and infected necrosis, what type of tissue do we want? A review. Dent. Traumatol., 28(1):13-8, 2012.

Andreasen, J. O.; Andreasen, F. M. \& Andersson, L. Textbook and Color Atlas of Traumatic Injuries to the Teeth. 4th ed. Hoboken, Wiley, 2013.

Barrett, E. J. \& Kenny, D. J. Avulsed permanent teeth: a review of the literature and treatment guidelines. Endod. Dent. Traumatol., 13(4):153-63, 1997.

Bourne, G. H. \& Wilson, E. M. H. Structural Aspects of Aging. New York, Hafner Publishing Company Inc., 1963.

Burley, M. A. \& Reece, R. D. Root formation following traumatic loss of an immature incisor. A case report. $B r$. Dent. J., 141(10):315-6, 1976.

Gibson, A. C. L. Continued root development after traumatic avulsion of partly-formed permanent incisor. $\mathrm{Br}$. Dent. J., 126(8):356-7, 1969.

Glendor, U. Epidemiology of traumatic dental injuries--a 12 year review of the literature. Dent. Traumatol., 24(6):60311, 2008.

Kling, M.; Cvek, M. \& Mejare, I. Rate and predictability of pulp revascularization in therapeutically reimplanted permanent incisors. Endod. Dent. Traumatol., 2(3):83-9, 1986.

Kristerson, L. \& Andreasen, J. O. Autotransplantation and replantation of tooth germs in monkeys. Effect of damage to the dental follicle and position of transplant in the alveolus. Int. J. Oral Surg., 13(4):324-33, 1984.

Rule, D. C. \& Winter, G. B. Root growth and apical repair subsequent to pulpal necrosis in children. Br. Dent. J., 120(12):586-90, 1966.

Welbury, R. \& Walton, A. G. Continued apexogenesis of immature permanent incisors following trauma. $\mathrm{Br}$. Dent. J., 187(12):643-4, 1999.
Correspondence to:

Jaime A. Díaz Meléndez

Profesor Asociado Adjunto

Especialista en Odontología Pediátrica

Director Especialidad Odontopediatría

Facultad de Odontología

Universidad de La Frontera

Temuco

CHILE

Email: jaimediaz@ufrontera.cl

Received: 12-11-2015

Accepted: 17-10-2016 